\title{
RETROPECTIVE ANALYSIS OF 25 CASES WITH BORDERLINE OVARIAN TUMORS
}

\author{
Safak Yilmaz BARAN, Behiye Pinar Cilesiz GOKSEDEF, Husnu GORGEN, Ahmet ÇETIN
}

Department of Obstetrics and Gynecology, Haseki Education and Research Hospital, Istanbul, Turkey

\begin{abstract}
SUMMARY
Objective: To determine the borderline ovarian tumors according to clinical features, treatment methods, recurrence and survival rates.

Material and methods: Twenty-five cases were included to this study. Demographic and clinical findings, surgical methods, stage of disease, recurrences and survivals were revealed from hospital records. Data were analyzed with SPSS 13.0.

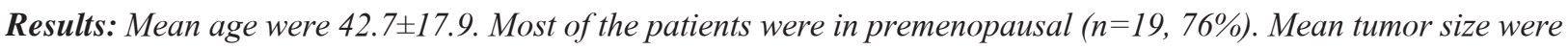
$13.44 \pm 9.37 \mathrm{~cm}$ (range $4-30 \mathrm{~cm}$ ) and 16 of the patients had serous and 9 of them had musinous histologic type. Mean tumor size of serous and mucinous tumors were $9.44 \pm 6.78 \mathrm{~cm}, 20.56 \pm 9.4 \mathrm{~cm}$, respectively and the difference was statistically significant ( $p=0.007)$. Tumor markers were elevated in 17 of the patients (68\%) before the surgery. Twenty-two patients had frozen section (88\%), accuracy rate of the frozen section was $90 \%$. during surgery. Most of the patients were treated with total abdominal hysterectomy bilateral salpingo-oophorectomy (TAH-BSO) ( $n=12)$, 6 of the patients were treated with cystectomy and the others were treated with unilateral oophorectomy (USO) ( $n=7)$. Most of the cases were stage I $(n=23,92 \%)$. Recurrence of the disease was detected in 4 patients $(16 \%)$ and 2 of them were treated with cystectomy and the others were treated with USO. No recurrence was detected in TAH-BSO group. Conclusions: Borderline tumors have perfect prognosis and most of the cases are premenopausal. The suggested treatment is surgical staging with TAH-BSO. Cystectomy might be chosen in young patients with fertilty desire, however, patients should be warned for high recurrence rates.
\end{abstract}

Key words: borderline ovarian tumor, histologic type, tumor markers, recurrence, survival

Journal of Turkish Society of Obstetrics and Gynecology, (J Turk Soc Obstet Gynecol), 2011; Vol: 8 Issue: 2 Pages: 107- 12

\section{ÖZET}

\section{BORDERLINE OVER TÜMÖRLÜ 25 OLGUNUN RETROSPEKTIFF ANALIZİ}

Amaç: Borderline over tümörlü vakaların klinik özellikleri ile birlikte uygulanan tedavi yöntemleri, rekürrens ve sağkalım oranlarının ortaya konulmasıdır.

Gereç ve yöntemler: Bu çalışmaya 25 borderline over tümörü olgusu dahil edildi. Retrospektif olarak olguların dosya kayıtlarından demografik ve klinik bulguları, yapılan cerrahinin türü, hastalı̆̆ın evresi, rekürrens durumu ve sağkalım sürelerine ulaşıldr. Bulgular SPSS 13.0 ile analiz edildi.

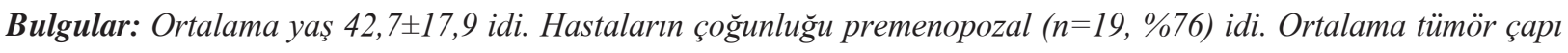

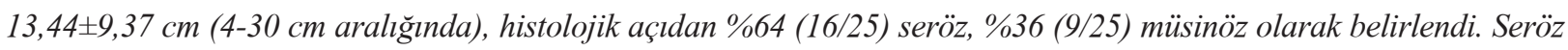

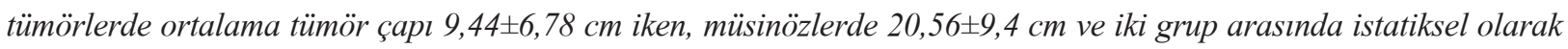
anlamlı fark saptandı ( $p=0,007)$. Cerrahi öncesinde tümör belirteçleri 17 hastada yüksek saptandı (\%68). Yirmiiki hastada frozen kesit uygulandı (\%88), frozen doğruluk oranı \%90 olarak belirlendi. Olguların 12 'si total abdominal histerektomi

Address for Correspondence: Dr. Safak Yilmaz Baran. Köprübaşı mah. 8.sok. Kengeroğlu apt. A Blok, D: 1 Göksun, Kahramanmaraş, Turkey Phone: +90(505) 5830856

e-mail: sayilmaz129@hotmail.com

Received: 15 October 2010, revised: 15 November 2010, accepted 18 January 2011, online publication: 14 March 2011 
bilateral salpingoooferektomi (TAH-BSO), 6 olgu kistektomi, 7 olgu unilateral salpingoooferektomi (USO) ile tedavi edildi. Olguların çoğunluğu evre 1 (n=23, \%92) idi. Rekürrens 4 olguda saptandı (16\%) ve 2 'si sadece kistektomi ile diğer 2 'si ise unilateral ooferektomi ile tedavi edilen olgulardı. TAH-BSO ile tedavi edilen olgularda rekürrens görülmedi. Sonuç: Borderline tümörler sıklıkla premenopozal dönemde görülen, çok iyi prognoza sahip lezyonlardır. Önerilen tedavi TAH-BSO, cerrahi evrelemedir. Kistektomi, fertilite isteği olan genç olgularda seçilebilir ancak hasta yüksek rekürrens oranları açısından uyarılmalıdır.

Anahtar kelimeler: borderline over tümörü, histolojik tip, rekürrens, sağkalım, tümör belirteçleri

Türk Jinekoloji ve Obstetrik Derneği Dergisi, (J Turk Soc Obstet Gynecol), 2011; Cilt: 8 Sayl: 2 Sayfa: 107- 12

\section{INTRODUCTION}

Borderline ovary tumor (BOT) was first defined as half-malign ovary tumor(1) in 1929 and classified among ovary tumors by FIGO in 1971 and by WHO in $1973^{(2,3)}$. It constitutes $10-15 \%$ of epithelial ovarian cancers and is associated with similar risk factors $(4)$. It is frequently seen in premenopausal women and these tumors have a strong prognosis. It is most frequently seen between the ages $30-50^{(5)}$.

It has similar clinical manifestations to those in other adnexal masses. It may be asymptomatic or there may be symptoms like abdominal pain and distention. Tumor diameter may be $<1 \mathrm{~cm}$ in serous tumors whereas in mucinous tumors it may be determined in a wide range up to $>30 \mathrm{~cm}^{(6,7)}$.

Surgery is the main treatment for borderline ovary tumors. In early stage cases, it is reliable and efficient to perform a laparoscopic procedure guided by an experienced laparoscopist but cyst rupture risk should be taken into consideration ${ }^{(8,9)}$. While it is possible to protect uterus and contra lateral ovary in premenopausal cases where fertility is desired(10), TAH-BSO is the most suitable choice in postmenopausal patients. Staging procedures include peritoneal lavage, peritoneal and omentum biopsies and appendectomy (especially in mucinous tumors). While routine pelvic and paraaortic lymph node dissection is controversial; it may not be required if no enlarged lymph node or suspected invasive lesion according to the frozen section is present $(11,12)$.

In this study, it was aimed to determine the clinical features, treatment methods, recurrence and survival rates of the borderline ovary tumor cases that have been surgically treated in our clinic.

\section{MATERIAL AND METHODS}

25 borderline ovary tumor cases that attended to our clinic between the dates 2003-2009 and were treated and followed were enrolled in this study. Approval of ethics committee was taken. Records of the cases were inspected retrospectively. Patients' age, presenting complaints, number of children, menopausal situation, family history, previous ovary cyst operation history, whether infertility treatment was done or not, preoperative ultrasonographic findings and if additional monitoring methods were used or not, tumor diameter and tumor markers were recorded. CA125 level $<35 \mathrm{IU} / \mathrm{ml}$ and CA19-9 level $<37 \mathrm{IU} / \mathrm{ml}$ were regarded as normal. Information regarding surgical method used in the treatment of the cases, whether staging and systematic lymphadenectomy was done and tumor stages and histological types from the pathology reports were collected. Follow-up times, presence and time of recurrence information was collected from the records. Information was analyzed with SPSS 13.0. In statistical evaluation, together with descriptive analysis, Mann-Whitney-U and Chi-Square methods were used in comparing the cases with and without recurrence development. $p<0.05$ value was regarded as statistically significant.

\section{RESULTS}

The mean age was $42,7 \pm 17,9$. Most of the cases were premenopausal $(n=19,76 \%)$. The most frequent presenting complaint was determined as abdominal pain. Infertility history was present in two cases. It was determined that one of these cases had used clomiphene citrate during 6 cycles for ovulation induction and the other had had no treatment. In one of the cases, ovary cancer was present in family history. Before diagnosis, tumor marker level was $68 \%(n=17)$ and frequently elevating marker was determined as 
CA $125(n=16,56 \%)$. It was observed that in addition to ultrasonography, one of the pre-operation monitoring methods, computed tomography (CT) or MRI was used in 17 cases. Clinical and demographical findings of the cases are shown in Table I.

Table I: Demographic and clinical characteristics of the cases.

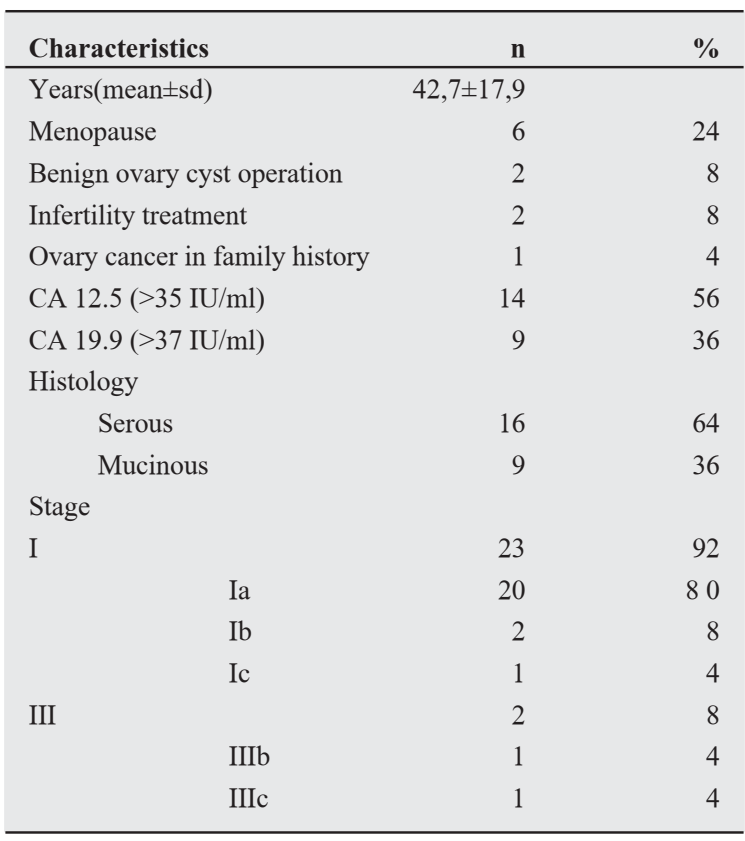

In the surgery, laparoscopic approach was used at the ratio of $16 \%(n=4)$ and incision by laparotomy at $84 \%$ $(n=21)$. Frozen section practice and accuracy ratios were $88 \%(n=22)$ and $90 \%(n=20)$ respectively. Cyctectomy was performed in six cases (24\%); unilateral oophorectomy in 7 cases $(28 \%)$ and total abdominal hysterectomy bilateral salpingoophorectamy (TAH-BSO) in 12 cases (48\%). In ten cases lymphadenectomy and staging surgery were performed. Of the cases in which staging was done, in 7; TAHBSO was performed $(70 \%)$ and in 3 ; conservative surgery was performed (30\%). In seven cases (70\%), appendectomy was added to staging surgery. Distribution of the cases among the applied surgical methods is outlined in Table II.

Mean tumor diameter was $13,44 \pm 9,37 \mathrm{~cm}$ (between 4-30 cm). Histologically, 64\% $(n=16)$ was of serous type and $36 \%(n=9)$ was of mucinous type. Mean mucinous type borderline tumor diameter was determined as significantly higher than mean serous type borderline tumor diameter (respectively; 20,56 $\pm 9,4$ $\mathrm{cm}$ and 9,44 $\pm 6,78 \mathrm{~cm}, \mathrm{p}=0.007)$. Lymph node invasion was determined in none of the lymphadenectomy performed cases. Of the 5 cases borderline tumor diagnosis of which was unknown in primary surgery; complementary surgery and staging was performed with a second operation in 2 cases.

Table II: Distribution of the cases by the method applied.

\begin{tabular}{ccc}
\hline & $\mathbf{n}$ & $\mathbf{\%}$ \\
\hline Surgical intervention method & 4 & 16 \\
Laparoscopy & 21 & 84 \\
Laparotomy & & \\
Operation performed & 6 & 24 \\
Cystectomy & 7 & 28 \\
Unilateral oophorectomy & & \\
TAH-BSO & & \\
Lymphadenectomy & 10 & 40 \\
Present & 15 & 60 \\
Not present & & \\
\hline
\end{tabular}

Most of the cases were stage $I(n=23,92 \%)$ and 2 patients were stage III $(n=2,8 \%) .20$ patients were stage Ia, 2 patients were stage $\mathrm{Ib}, 1$ patient was stage Ic, 1 patient was stage IIIb and 1 patient wastage IIIc. Microinvasive capsule implant was determined in 1 of the cases and microinvasive peritoneum implant in the other.

Mean follow-up time was 25,6 months (10-82 months). Recurrence was determined in 4 cases $(16 \%)$. Mean recurrence time was determined as 14,25 months (424 months). It was found out that all of the cases with recurrence had serous histology. Mean age and tumor diameter of the cases with recurrence development was found smaller compated to the cases without recurrence (respectively; for age, $25,7 \pm 5,5$ and 46 $\pm 17,6$, $\mathrm{p}=0,001$ and for tumor diameter, $9 \pm 2,1$ and $14,2 \pm 10,1$, $\mathrm{p}=0,04)$. No significant difference was determined among the cases with and without recurrence in terms of CA125 and CA 19.9 height, performance of cystectomy, USO and lymphadenectomy (Table III). In 2 of the recurrent cases, cystectomy was performed and USO was done in the other two. While recurrence ratio was $30 \%(4 / 13)$ in the conservative surgery performed cases, no recurrence $(0 / 12)$ was monitored among the TAH-BSO performed cases. Recurrence ratio was determined as significantly higher in the conservative surgery performed cases $(p=0.03) .3$ of the recurrent cases were stage Ia and one was stage IIIc. Oophorectomy was performed in 2 recurrent cystectomy cases and 2 cases that developed recurrence in the other ovary. Survival ratio among all the followed patients who was $100 \%$. 
Table III: Characteristics of the cases with and without recurrence.

\begin{tabular}{llll}
\hline & $\begin{array}{l}\text { Recurrence } \\
\text { present } \\
(\mathbf{n = 4 ) ( \% )}\end{array}$ & $\begin{array}{l}\text { Recurrence } \\
\text { not present } \\
(\mathbf{n = 2 1})(\%)\end{array}$ & $\mathbf{p}$ \\
\hline Age $(\mathrm{mean} \pm \mathrm{sd})$ & $25.7 \pm 5.5$ & $46 \pm 17.6$ & 0.001 \\
CA $12.5>35 \mathrm{IU} / \mathrm{ml}$ & $2(\% 14)$ & $12(\% 86)$ & 0.79 \\
CA $19.9>37 \mathrm{IU} / \mathrm{ml}$ & $1(\% 11)$ & $8(\% 89)$ & 0.61 \\
Tumor diameter(mean $\pm \mathrm{ss})$ & $9 \pm 2.1$ & $14.2 \pm 10.1$ & 0.04 \\
Cystectomy & $2(\% 33)$ & $4(\% 64)$ & 0.18 \\
USO & $2(\% 29)$ & $5(\% 71)$ & 0.28 \\
TAH-BSO & $0(\% 0)$ & $12(\% 100)$ & 0.03 \\
Lymphadenectomy & $2(\% 20)$ & $8(\% 80)$ & 0.65 \\
\hline
\end{tabular}

\section{DISCUSSION}

Compared to invasive ovary tumors, borderline ovary tumors are seen in smaller ages, have stronger prognosis, progress more slowly and recurs later. Therefore treatment approaches are less aggressive but still there are different opinions on some topics $(10,11)$. Though typical ultrasonographic findings are determined as positive crescent sign and unilocular cyst, disseminated papillary projections growing from the internal wall or cysts containing multilocular nodule, these findings aren't found in one third of the cases and they are recognized as preoperative benign cystic lesions $^{(12)}$.

In this study, it was determined that mean age was 42,7 and most of the cases were premenopausal and with serous histology. In the study done by Houck et al, 140 cases were evaluated; mean age was 52,3, mean tumor diameter was $13,7 \mathrm{~cm}(10,2 \mathrm{~cm}$ in serous tumors, $20,1 \mathrm{~cm}$ in mucinous tumors), histologically; $57,1 \%$ was of serous type, $33,5 \%$ was of mucinous type and $9,4 \%$ was of other types ${ }^{(13)}$.

In the analysis of 25 cases performed in our clinic retrospectively, tumor marker level was determined at the ratio of $68 \%$. But no relation could be shown between the high tumor markers and recurrence. Mean tumor diameter was $9,44 \pm 6,78 \mathrm{~cm}$ in serous tumors, $20,56 \pm 9,4 \mathrm{~cm}$ in mucinous tumors and statistically significant difference was determined among two groups $(p=0,007)$. In previous series, while higher tumor diameter $(13,1 \pm 7 \mathrm{~cm})$ was monitored in mucinous tumors ultrasonographically, smaller tumor diameter $(9,3 \pm 6,2 \mathrm{~cm})$ was seen in serous tumors ${ }^{(14)}$.

In the borderline ovary tumor cases in our clinic, it was monitored that frozen section was practiced at the ratio of $88 \%(22 / 25)$. Borderline tumor diagnosis was established in the frozen sections at the ratio of $90 \%$ and benign tumor was determined in 2 patients. In our series, frozen results of the cases with a final diagnosis of borderline were evaluated. Therefore, frozen section sensitivity and specifity values in the borderline ovary tumors can not be calculated. In a research, frozen section records of 48 borderline ovary tumor patients and it was shown that benign incidents could be excluded in frozen sections with a diagnostic accuracy of $94 \%$. But in BOT, diagnostic accuracy of the frozen sections decrease ${ }^{(15)}$. In the study of Houck et al, frozen section was evaluated as invasive cancer at the ratio of $20 \%$ and as benign at the ratio of $30 \%$ in the patients with BOT. In the permanent sections of the patients with BOT diagnosis in frozen sections, invasive cancer was determined at the ratio of $23-27 \%^{(13)}$. In two large researches done in the recent years, concordance ratios of frozen and permanent sections have been reported as $62 \%$ and $85 \%(16,17)$.

Base of the treatment in borderline ovary tumors is surgery. If fertility is desired, performance of cystecomy or oophorectomy is appropriate; but if the patient is not fertile anymore, then TAH-BSO surgical procedure is suitable. There are different opinions on whether to perform surgical staging or not. A survey study was done among 660 members of Gynecologic Oncology Group. 42 percent of them (274) responded. According to $97 \%$ surgical staging is required; to $96 \%$ peritoneal lavage; to $92 \%$ random peritoneal biopsy; to $97 \%$ omentectomy/ sampling; to $88 \%$ lymphadenec-tomy ( $89 \%$ para-aortic, $97 \%$ pelvic) $)^{(18)}$. In our study surgical staging was performed on 10 patients. In a research conducted among 15 patients between the years 1978-87, importance of staging was emphasized and in $46 \%$ of the cases, involvement outside the ovary was monitored in the patients for whom surgical staging was performed 3 months after the establishment of BOT diagnosis ${ }^{(19)}$. While deciding on surgical staging, tumor's being bilateral, exophytic involvement presence, $>10 \mathrm{~cm}$ mass presence, advanced stage disease, high recurrence risk should be taken into consideration $(21,22)$

In a study, conservative surgery was performed on 62 of 142 BOT patients and fertility sparing surgery was performed; recurrence ratio among patients was found as $6.5 \%$ and pregnancy ratios were indicated as $16 \%(23)$. In a meta-analysis including 2479 BOT patients, conservative surgery was performed; pregnancy 
occurred in $48 \%$ and recurrence was monitored in $16 \%$ of 923 patients ${ }^{(24)}$. Compared to the literature results, in our series pregnancy ratio is low and we believe the reasons for this are; our relatively shorter mean followup time, infertility in addition to borderline ovary tumor, the fact that some of the patients are single or don't have a partner and new pregnancy postponing of the cases who have children.

In the large serial study of Ayhan et al; 100 cases with BOT diagnosis were evaluated, comprehensive surgical staging was performed on 49 patients and fertility sparing surgery was performed on 22 . Recurrence ratio was determined as 3\% and general survival ratio as above $97.9 \%$. In this study no difference was determined between the cases with and without recurrence in terms of age, parity, microinvasion, micropapiller structure, FIGO stage, surgery type, preoperative serum CA125 levels and lymph node involvement but general survival ratios without tumor decreased significantly in the presence of micropapillary structure or peritoneal implants and in the fertility sparing surgery performed cases under the age 30. In the presence of serous BOT, it was suggested that conservative surgery practice and lymphadenectomy procedure can be performed in serous BOT cases only in academic studies, provided that other ovary is also evaluated ${ }^{(25)}$.

Recurrence ratios after fertility sparing surgery is 2,4$15 \%$ following adnexectomy and $15-36 \%$ following cystectomy. Cystectomy was performed in 53 patients with BOT stage I, recurrence was monitored in $30 \%$, 20 patients were re-operated and residual BOT was monitored in 3 patients $(15 \%)^{(26,27)}$.

In this study, recurrence was monitored in $33 \%$ of the cystectomy performed patients and $24 \%$ of the oophorectomy performed patients. Interestingly, mean ages and tumor diameters of the cases with recurrence were determined as lower than the ones without recurrence. The reason of this situation may be due to the bigger need for fertility sparing procedure performance in young ages or probability of recurrence/residual development in the other ovary. The fact that the cases with recurrence have smaller tumor diameters may be explained with the facts that all the recurrences in our series were seen in serous tumors and the mean serous tumor diameters are determined as smaller than those of the mucinous type.

Though this research is a limited study because of its retrospective nature and few cases; borderline ovary tumors are rare and a limited number of retrospective studies with few cases can be found in literature. Ideal method to be applied in treatment is not clear yet. Prominent finding of the retrospective analysis of the patients treated at our clinic is that recurrence frequency in fertility sparing aimed cystectomy and USO cases is significantly higher than the ones treated with TAHBSO. However, it should be known that when suspected from these tumors that may also be seen in young cases where fertility is desired, frozen section should be performed during operation and fertility sparing surgery procedures such as cystectomy and oopherectomy may be performed. But, due to the high ratios following this type surgery procedures, patients should be informed in terms of recurrence and followed.

\section{REFERENCES}

1. Taylor HC. Malignant and semimalignant tumors of the ovary. Surg Gynecol Obstet 1929; 48: 204- 30.

2. Classification and staging of malignant tumors in the female pelvis. Acta Obstet Gynecol Scand 1971; 50: 1- 7 .

3. Serov SF, Scully RE, Sobin LH. Histologic typing of ovarian. In: International classification and staging of tumors. Number 9. Geneva: World Health Organization 1973: 37- 8.

4. Huusom LD, Frederiksen K, Høgdall EV, Glud E, Christensen L, Høgdall CK, Blaakaer J, Kjaer SK. Association of reproductive factors, oral contraceptive use and selected lifestyle factors with the risk of ovarian borderline tumors: a Danish casecontrol study. Cancer Causes Control. 2006 Aug;17(6): 8219.

5. Scully RE, Young RH, Clement PB. Tumors of the ovary, maldeveloped gonads, fallopian tube, and broad ligament. In atlas of tumor pathology. Washington: Armed Forces Institude of Patholog; 1998; Fascicle23, 3rd series.

6. Schorge J, Schaffer J,Halvorson L, Hoffman B, Bradshaw K, Cunningham F. Epithelial ovarian cancer. Williams Gynecology. McGraw-Hill Companies, United States 2008; 719- 21.

7. Berek J. Over kanseri. Novak Jinekoloji.13.edt. Nobel Tip Kitabevleri, İstanbul 2004; 1246- 50.

8. R. Seracchioli, S. Venturoli, F.M. Colombo, F. Govoni, S. Missiroli, A. Bagnoli, Fertility and tumor recurrence rate after conservative laparoscopic management of young women with early-stage borderline ovarian tumors, Fertil Steril 2001; 76: 999- 1004.

9. Tinelli R, Malzoni M, Cosentino F, Perone C, Tinelli A, Malvasi A, Cicinelli E. Feasibility, safety, and efficacy of conservative laparoscopic treatment of borderline ovarian tumors. Fertil 
Steril. 2009; 92(2): 736- 41.

10. Zanetta G, Rota S, Chiari S, Bonazzi C, Bratina G, Mangioni C. Behavior of borderline tumors with particular interest to persistence, recurrence, and progression to invasive carcinoma: a prospective study. J Clin Oncol. 2001 May 15; 19(10): 2658- 64.

11. Rao GG, Skinner EN, Gehrig PA, Duska LR, Miller DS, Schorge JO. Fertility-sparing surgery for ovarian low malignant potential tumors. Gynecol Oncol. 2005 Aug; 98(2): 263- 6.

12. Yazbek J, Raju KS, Ben-Nagi J, Holland T, Hillaby K, Jurkovic D. Accuracy of ultrasound subjective 'pattern recognition' for the diagnosis of borderline ovarian tumors. Ultrasound Obstet Gynecol. 2007 May; 29(5): 489- 95.

13. Houck K, Nikrui N, Dusca L, Chang Y, Fuller A, Bell D, Goodman A. Borderline Tumors of the Ovary: Correlation of Frozen and Permanent Histopathologic Diagnosis.Obstet Gynecol. 2000; 95(6): 839- 43.

14. Gotlieb WH, Soriano D, Achiron R, Zalel Y, Davidson B, Kopolovic J, Novikov I, Ben-Baruch G. CA 125 measurement and ultrasonography in borderline tumors of the ovary. Am J Obstet Gynecol. 2000; 183(3): 541- 6.

15. Menzin AW, Rubin SC, Noumoff JS, LiVolsi VA. The accuracy of a frozen section diagnosis of borderline ovarian malignancy. Gynecol Oncol. 1995; 59(2): 183- 5.

16. Kim JH, Kim TJ, Park YG, Lee SH, Lee CW, Song MJ, Lee KH, Hur SY, Bae SN, Park JS. Clinical analysis of intraoperative frozen section proven borderline tumors of the ovary. J Gynecol Oncol. 2009 Sep; 20(3): 176- 80.

17. Gorisek B, Stare MR, Krajnc I. Accuracy of intra-operative frozen section analysis of ovarian tumours. J Int Med Res. 2009 Jul-Aug; 37(4): 1173- 8.

18. Menzin AW, Gal D, Lovecchio JL. Contemporary surgical management of borderline ovarian tumors: a survey of the Society of Gynecologic Oncologists. Gynecol Oncol. 2000 Jul; 78(1): 7- 9 .
19. Hopkins MP, Morley GW. The second-look operation and surgical reexploration in ovarian tumor of low malignant potential. Obstet Gynecol. 1989 Sep; 74(3 Pt 1): 375- 8.

20. Seidman JD, Ronnett BM, Kurman RJ. Pathology of borderline (low malignant potential) ovarian tumours. Best Pract Res Clin Obstet Gynaecol. 2002 Aug; 16(4): 499- 512.

21. Kanat-Pektas M, Ozat M, Gungor T, Sahin I, Yalcin H, Ozdal B. Complete lymph node dissection: is it essential for the treatment of borderline epithelial ovarian tumors? Arch Gynecol Obstet. 2010 Jun 13. Epub ahead of print.

22. Fotopoulou C, Schumacher G, Schefold JC, Denkert C, Lichtenegger W, Sehouli J. Systematic evaluation of the intraoperative tumor pattern in patients with borderline tumor of the ovary. Int J Gynecol Cancer. 2009 Dec; 19(9): 15505 .

23. Boran N, Cil AP, Tulunay G, Ozturkoglu E, Koc S, Bulbul D, Kose MF. Fertility and recurrence results of conservative surgery for borderline ovarian tumors. Gynecol Oncol. 2005 Jun; 97(3): 845- 51.

24. Swanton A, Bankhead CR, Kehoe S. Pregnancy rates after conservative treatment for borderline ovarian tumours: A systematic review. Eur J Obstet Gynecol Reprod Biol. 2007 Nov; 135(1): 3- 7

25. Ayhan A, Guvendag Guven ES, Guven S, Kucukali T. Recurrence and prognostic factors in borderline ovarian tumors.Gynecol Oncol. 2005 Sep; 98(3): 439- 45.

26. Poncelet C, Fauvet R, Boccara J, Daraï E. Recurrence after cystectomy for borderline ovarian tumors: results of a French multicenter study. Ann Surg Oncol. 2006 Apr; 13(4): 56571.

27. Morice P, Camatte S, El Hassan J, Pautier P, Duvillard P, Castaigne D. Clinical outcomes and fertility after conservative treatment of ovarian borderline tumors. Fertil Steril. 2001 Jan; 75(1): 92- 6 